\title{
PRA NÃO DIZER QUE NÃO FALAMOS DE ESPINHOS: A CONSTITUCIONALIZAÇÃO DO DIREITO CIVIL E A DIFÍCIL CONCRETIZAÇÃO DA IDEIA DE REPERSONALIZAÇÃO EM AÇÕES DE DIREITOS REAIS NOS TRIBUNAIS BRASILEIROS ${ }^{1}$
}

\author{
Luiz Gonzaga Silva Adolfo \\ Paula Cristina Koerig de Oliveira ${ }^{3}$
}

\begin{abstract}
De uma penada, doou ao vistoso casal os títulos de propriedade de uma fazenda e milhares de cabeças de gado, já que entre as suas atribuições estava a de distribuir terras entre os colonos. Traçou o contorno num mapa seguindo o impulso do lápis; depois, quando averiguaram os limites reais da fazenda, viram que eram incontáveis hectares de pastagens, colinas, matas, rios e praia. Eram necessários vários dias para percorrer a propriedade a cavalo: era a maior e mais bem localizada da região. ${ }^{4}$
\end{abstract}

\section{RESUMO}

O artigo se propõe a analisar, mesmo que brevemente, a construção teórica da corrente hermenêutica denominada "constitucionalização do Direito Civil", e nela a ideia de "repersonalização", bem como a ocorrência ou não destas ideias na fundamentação de decisões em sede de Direitos Reais em alguns Tribunais brasileiros.

Palavras-Chave: Constitucionalização. Direito de Propriedade. Direitos Reais. Função Social da Propriedade. Princípios Constitucionais. Repersonalização.

\section{INTRODUÇÃO}

0 presente estudo tem como intuito destacar alguns aspectos que envolvem a evolução do direito à propriedade, bem como sua função social, sob o prisma de um Direito Civil Constitucional, para num segundo instante enfatizar a ideia de "repersonalização", e se esta vertente hermenêutica chegou até as decisões de Direitos Reais nos Tribunais pátrios.

Buscou-se analisar uma nova visão do Direito de Propriedade, que aponta o efetivo alcance de sua função social, ${ }^{5}$ ou seja, uma vertente mais atual e renovada do Direito Privado, num primeiro instante através do abrandamento da antiga dicotomia entre as duas grandes áreas historicamente fixadas pela doutrina tradicional para o Direito (Público e Privado) e num segundo instante pela necessária constitucionalização do Direito Privado.

Partiu-se da necessária interpretação que deve ser dada a esta área do Direito, especialmente a partir das inovações trazidas pelo atual Código Civil (Lei no 10.406, de 11 de janeiro de 2002, que entrou em vigor em 11 de janeiro de 2003), que trazem em seu bojo, como já fez antes a Constituição Federal de 1988, o que doutrinariamente a consagrou como "repersonalização"e "constitucionalização". 
Num mundo de tantas complexidades, interesses e diversidades, impende adequar-se às mudanças que surgem na sociedade. Nesta linha de mira, é importante a percepção de que as disposições inseridas na Carta Constitucional alteraram qualitativamente o conteúdo das categorias analisadas, num movimento de ruptura, buscando atender as aspirações da sociedade brasileira no limiar do novo século, possibilitando que 0 Direito acompanhe a evolução e 0 desenvolvimento da sociedade.

Para atingir os objetivos, a metodologia utilizada partiu da Hermenêutica Jurídica, com pesquisa teórica introdutória, demonstrando algumas características, bem como os principais pensadores que trabalham nesta perspectiva para, na sequência, efetivar uma investigação jurisprudencial no Supremo Tribunal Federal STF, no Superior Tribunal de Justiça - STJ e em oito dos principais Tribunais de Justiça estaduais do Brasil (Rio Grande do Sul, Santa Catarina, Paraná, São Paulo, Rio de Janeiro, Minas Gerais, Bahia e Pernambuco), efetivamente comprovando a adoção, ou não, desta corrente e da ideia de repersonalização em ações que discutem Direitos Reais em nosso país, confirmando-se ou não a vinculação do Direito infraconstitucional aos princípios constitucionais.

\section{FORTE CUNHO PATRIMONIALIZANTE DO DIREITO CIVIL E AS TENDÊNCIAS DE REPERSONALIZAÇÃO}

Para se perpassar a origem da perspectiva dicotômica entre o Direito Público e o Direito Privado, por suas significações, torna-se necessária sua análise histórica, pois somente na História e só nela são compreendidas. ${ }^{6}$

Através do fenômeno da codificação, a burguesia, ao ascender ao poder político no período iluminista, entre o final do século XVIII e final do século XIX, consagrou no plano jurídico a exacerbação do patrimônio como um fim em si mesmo, com um valor absoluto, exclusivo e perpétuo. ${ }^{7}$

O Código Civil de 1916 repetiu o modelo de codificação do século XIX, sendo que em pleno século $X X$ trouxe para seu texto concepções filosóficas típicas do período iluminista e, como destaca Tepedino, possuía como característica marcante "o caráter monopolizador das relações privadas", por isso conhecido como a Constituição do Direito Privado. ${ }^{8}$ Conseguintemente, a propriedade era 0 valor absoluto, ilimitado e necessário para a realização da pessoa humana, a qual figurava nas relações jurídicas como sujeito abstraído de sua dimensão real. A classe burguesa conservava o status quo que lhe interessava mantendo as desigualdades sociais e os desequilíbrios econômicos a seu favor.

Como bem enfoca Martins-Costa, nesta visão o Direito Privado designaria historicamente a compreensão de regras ordenadas nos Códigos Civil e Comercial e esparsamente em algumas leis especiais, com base no tripé pessoa, família e patrimônio, ou as pessoas, os bens e suas relações, na indicação do artigo $1^{\circ}$ do Código Civil de 1916. Desta forma,

O Direito Privado seria nada mais, nada menos do que um conjunto de regras técnicas, neutras, apolíticas, reguladoras da atividade interprivada. Esta seria, por sua vez, mobilizada pelo princípio da autonomia privada visto 
ao modo individualista, 'egoístico' e voluntarista refletido na expressão 'autonomia de vontade', apartado, porque absoluto e absolutizante, de outros eixos valorativos. ${ }^{9}$

Percebe-se que neste momento histórico o paradigma do capitalismo definia o êxito pessoal como sinônimo de acúmulo de bens. Diante disto, restava ao indivíduo desprovido de riqueza patrimonial alienar seu único meio de sobrevivência, ou seja, a força de trabalho. ${ }^{10}$

Como faz notar Fachin, a história do Brasil nos três primeiros séculos está relacionada à da expansão comercial e colonial da Europa moderna, visualizando, neste contexto, "um Brasil que nasce na miscigenação e se funda na exclusão social, traço que perdura desde a herança colonial". Nascimento de uma Nação em que submissão e subordinação, encontro e ocupação, se entrelaçam mediante diversos instrumentos de realização, consolidação e expansão do poder político e econômico. ${ }^{11}$

Destaca-se, ainda, que os elementos culturais de caracterização social nucleados nesta perspectiva vão alcançar as bases do Estado brasileiro, ou seja, um Estado cartorial, edificado pelo reino da solenidade e celebrações, ritos e processos, que de certa maneira encontra em seus primórdios o empreguismo público, a exclusão social e uma seleta classe dominante, afortunada e poderosa, imune ao crivo da lei e ao aparato estatal.

Assim, verifica-se que o Código Civil de 1916 se prestava como um meio legal de garantia das elites econômicas do país contra as intervenções e ingerências estatais no livre mercado. Na dicção de Tepedino,

O Código Civil, bem se sabe, é fruto das doutrinas individualista e voluntarista que, consagradas pelo Código de Napoleão e incorporadas pelas codificações do século XIX, inspiraram o legislador brasileiro quando, na virada do século, redigiu o nosso Código Civil de 1916. Àquela altura, o valor fundamental era 0 indivíduo. $O$ direito privado tratava de regular, do ponto de vista formal, a atuação dos sujeitos de direito, notadamente o contratante e o proprietário, os quais, por sua vez, a nada aspiravam senão ao aniquilamento de todos os privilégios feudais: poder contratar, fazer circular as riquezas, adquirir bens como expansão da própria inteligência e personalidade, sem restrições ou entraves legais. Eis aí a filosofia do século $\mathrm{XIX}$, que marcou a elaboração do tecido normativo consubstanciado no Código Civil. ${ }^{12}$

Este cenário perdurou por muito tempo, até a Constituição Federal de 1988 que, atendendo aos anseios sociais, alterou radicalmente todo o Direito Civil com a consagração, no inciso III do artigo 1ํ, do princípio da dignidade da pessoa humana como um dos fundamentos da República Federativa do Brasil. ${ }^{13}$

Além da consagração do princípio da dignidade da pessoa humana, percebese a convolação de visão relacionada ao Direito Privado. Ou seja, a mudança de enfoque centralizador do Código Civil levou a uma "despatrimonialização". O núcleo central, que era o patrimônio, passou a ter como centro a pessoa e suas necessidades fundamentais, levando a sociedade a repensar sobre a importância que se deve atribuir à personalidade, aos hipossuficientes, à garantia do patrimônio mínimo, como o bem de família e o módulo rural, bem como da tutela da vida 
àqueles a quem se destina a norma civil. ${ }^{14}$

Este novo enfoque, com a discussão dos princípios e dos valores que o sistema jurídico colocou em seu centro e em sua periferia, é o que se chama de "repersonalização", como logo se verá.

\subsection{A "repersonalização" e a "constitucionalização" do Direito Privado}

Com a promulgação da Constituição Federal de 1988, todo o ordenamento infraconstitucional precisou ser adaptado à nova moldura imposta pelas normas superiores, ou seja, "o Código curva-se ante o manto Constitucional dos valores que ofuscam a ideologia que o inspirou", e "a abertura do sistema lhe dá uma convergência social irresistível". ${ }^{15}$ Delineia-se aí a expressão "Constitucionalização do Direito Privado".

Nesta toada, há uma mudança substancial, ou seja, "deve o jurista interpretar - Código Civil segundo a Constituição e não a Constituição segundo o Código, como ocorria com freqüência". 16 Assim, a "repersonalização" do Direito Civil está relacionada com a emancipação da pessoa humana, colocando-a como centro do Direito Civil, passando o patrimônio ao papel coadjuvante. É o que propõe Perlingieri quando diz que 'uma coisa é ler o Código naquela ótica produtivista, outra é 'relê-lo' à luz da opção 'ideológico-jurídica' constitucional, na qual a produção encontra limites insuperáveis no respeito aos direitos fundamentais da pessoa humana"."17

Aronne argutamente destaca, neste contexto, que o compromisso transformador, inerente à ideia de Estado Social e Democrático de Direito, publiciza o Direito Civil com vistas à sua "repersonalização", através dos mecanismos normativos do sistema, ampliando o interesse recebido nas titularidades, visando, assim, sua funcionalização, na condição de meio de concretização dos valores solidarísticos constitucionalizados. ${ }^{18}$

Pode-se afirmar, em síntese, que a discussão dos princípios e valores que o sistema jurídico colocou em seu centro e em sua periferia é o que se chama de "repersonalização" do Direito Privado. ${ }^{19}$ Desta angulação, é possível perceber uma mudança de mentalidade da sociedade, a qual faz repensar também o Direito, recolocando o indivíduo como ser coletivo, no centro dos interesses e na perspectiva da igualdade substancial. ${ }^{20}$

A partir da constitucionalização do Direito Civil, é necessário que os civilistas assumam o desafio de perceber a pessoa em toda a sua dimensão ontológica e, através dela, seu patrimônio. Devem ser levados em consideração os princípios constitucionais nas relações do Direito Privado, reconhecendo o caráter normativo de princípios como o da solidariedade, da dignidade da pessoa humana e da função social da propriedade, pois através deles é possível assegurar eficácia imediata a tais relações. ${ }^{21}$

Lôbo destaca que a constitucionalização "é o processo de elevação ao plano constitucional dos princípios fundamentais do Direito Civil, que passam a condicionar a observância, pelos cidadãos, e a aplicação, pelos tribunais, da legislação 
infraconstitucional", 22 e Fachin enfoca que a constitucionalização "significa o processo pelo qual a Constituição vai gerar mudança que irá repercutir no Direito Civil". 23

A idéia de constitucionalização do Direito está ligada a um efeito expansivo das normas constitucionais, onde o conteúdo material e axiológico se irradia, com força normativa, por todo o sistema jurídico. "Os valores, os fins públicos e os comportamentos contemplados nos princípios e regras da Constituição passam a condicionar a validade e 0 sentido de todas as normas do Direito infraconstitucional". ${ }^{24}$

As disposições inseridas na Carta Constitucional alteraram qualitativamente o conteúdo das categorias analisadas, buscando atender às necessidades da sociedade brasileira no limiar do novo século. Consequentemente, ao recepcionar temas que na dicotomia histórica eram compreendidos no Estatuto Privado, a Constituição Federal de 1988 gerou transformações consideráveis no sistema de Direito Civil clássico.

A propriedade privada, como direito individual, foi disciplinada juridicamente a partir do Código Civil francês em 1804, em seu artigo 554, em que se destacava o direito de propriedade como um direito absoluto no centro do ordenamento, reproduzindo as idéias econômicas do início do século XIX, através da propriedade liberal. Sendo assim, serviu o Código da França de inspiração ao Código Civil brasileiro de 1916, que colocou a família, a propriedade privada individual e a autonomia da vontade como pilares de sustentação do sistema jurídico privado, servindo, desta maneira, como expressão de positivação do Direito Natural. ${ }^{25}$

Com o desfazimento da moldura individualista, a concepção de propriedade vem apanhando feição normativa com ares coletivos nos mais diversos ordenamentos jurídicos do globo, sendo expressamente recepcionada pela Constituição de 1988 , no artigo $5^{\circ}$, que trata das garantias e direitos individuais, em seu inciso XXIII, afirmação positiva de que "a propriedade atenderá sua função social".

Neste sentido, pode-se decifrar que houve um deslocamento da centralidade, do Código para a Constituição Federal e leis especiais. Assim, as garantias passaram genericamente para a Constituição e particularmente para as leis especiais. Ressalta-se, ainda, que na Constituição, como decorrência de um sistema que deveria se subordinar ao ordenamento fixado a partir de 1988; nas leis especiais, que foram muitas após o Código Civil de 1916, muitas vezes abrangendo matérias inteiras, como condomínio, parcelamento de solo, divórcio, a criança e o adolescente, direitos dos consumidores e meio ambiente, entre outros. ${ }^{26}$ Nas palavras sempre autorizadas de Ferrajoli, a história da propriedade privada, da empresa e do Direito de Família é em grande parte uma história das progressivas limitações das prerrogativas privadas para tutela dos direitos fundamentais. ${ }^{27}$

Outro aspecto interessante e que deve ser verificado refere-se à adoção de cláusulas gerais, as quais possibilitam a atividade interpretativa mais criadora, já que utiliza em seu enunciado uma linguagem mais aberta, fluída, caracterizando-se pela ampla extensão de seu campo semântico, que podem ser importantes instrumentos 
de flexibilização do sistema. Elas serão brevemente enfocadas na seqüência.

\subsection{As cláusulas gerais}

De acordo com Martins-Costa, o Código Civil na contemporaneidade não tem mais por paradigma a estrutura de um modelo fechado, do sistema oitocentista de código totalitário. No entanto, não se pode, igualmente, superar a idéia de codificação. Deve-se considerar a forma desta codificação, pois a partir da Constituição, farta em modelos jurídicos abertos, a linguagem codificada não estaria mais restrita à rígida descrição de fattispecies cerradas, à técnica da casuística, já que "num Código não-totalitário tem janelas abertas para a mobilidade da vida, pontes que o ligam a outros corpos normativos - mesmo os extrajurídicos - e avenidas bem trilhadas que 0 vinculam, dialeticamente, aos princípios e regras constitucionais". ${ }^{28}$

As cláusulas gerais têm a vantagem da mobilidade, proporcionada pela intencional imprecisão da fattispecie que contêm, afastando o risco do imobilismo; porquanto, é utilizado em grau mínimo o princípio da tipicidade. Perlingieri mostra-se adepto desta possibilidade ao defender que, ao lado da técnica legislativa com normas regulamentares (previsões específicas e circunstanciadas), se apresenta a técnica das cláusulas gerais, o que redunda deixar ao juiz, ao intérprete, uma maior possibilidade de adaptar as normas às situações fáticas. ${ }^{29}$ Vale ressaltar, ainda, que as normas constitucionais mais amplas e abertas, assimilam com maior facilidade as mudanças sociais, proporcionando ao Judiciário uma adaptação mais rápida aos novos valores sociais, auxiliando sua interpretação. Nesta mira, Tepedino salienta que:

\footnotetext{
Parece indiscutível a necessidade de se desenvolver, por parte do legislador e do intérprete, a técnica das cláusulas gerais, cuja noção evita as profundas lacunas causadas pela evolução da sociedade; sendo impossível ao legislador acompanhar o passo dos acontecimentos, e infrutífera a tentativa de tipificar a totalidade das situações jurídicas que, assim como os bens jurídicos objeto do direito, multiplicam-se a cada momento. ${ }^{30}$
}

Dentre as principais cláusulas gerais adotadas pelo Código Civil de 2002 encontra-se a função social da propriedade, diretamente relacionada aos Direitos Reais e que será melhor trabalhada posteriormente.

A propriedade, que sempre apresentou um foco constante de tensões sociais e econômicas, gerando instabilidade nas relações jurídicas, teve sua função social destacada no artigo 5, inciso XXIII, afirmando, expressis verbis, que "a propriedade atenderá sua função social'".

Com o advento do novo Código Civil, especificamente o artigo 1.228, passouse a dar contorno de efetividade ao princípio constitucionalmente estabelecido. Assim, dando cumprimento ao cânone constitucional, o legislador infraconstitucional, no dispositivo citado, determina, quando do exercício do direito de propriedade, 0 respeito à flora, à fauna, às belezas naturais, ao equilíbrio ecológico e ao patrimônio histórico e artístico, bem como seja evitada a poluição do ar e das águas. ${ }^{31}$ 
Põe-se, desta forma, importante e eficaz meio de concretização plena de um novo Direito, considerando ainda, para que isso ocorra, que são necessárias razoáveis mudanças de visão e ação do intérprete, pois elas não atingirão seu fim se o próprio Código for interpretado nos moldes da dogmática da pretensa completude sistemática. $^{32}$

\subsection{A propriedade e sua função social no novo Código Civil}

O Código Civil vigente traz em seu bojo alguns institutos de nítida visão social, muitos dos quais a partir de cláusulas gerais ou abertas. Fez certa adequação da legislação infraconstitucional à Constituição Federal, que antes somente era feita por meio de um processo hermenêutico de 'filtragem".

Por primar o atual Código em valores como eticidade, operabilidade e socialidade, vários foram os institutos inseridos e outros atualizados, em uma visão mais atual, concreta e transformadora do Direito Civil, dentre eles a função social da propriedade, seguramente o mais comentado instituto de cariz social deste Digesto.

A propriedade, tratada desde os primórdios da civilização, anterior às moedas cunhadas em ouro, prata ou bronze, tem ocupado grande espaço dos doutrinadores, especialmente dos juristas dedicados à matéria, sociólogos, antropólogos e de uma parcela significativa da sociedade preocupada ou comprometida com as questões sociais.

O Direito Romano e o liberalismo econômico definiam a propriedade como o direito de usar e de dispor da coisa. Entretanto, o Direito contemporâneo impôs sobre ela certas limitações, como forma de equacionar seu uso, levando em consideração que o convívio em sociedade exige a composição entre seus interesses com os direitos superiores do Estado.

Duguit foi um dos principais filósofos e doutrinadores a dar início à corrente de pensamento jurídico para a elaboração de textos constitucionais que enfatizaram a função social da propriedade. Em texto que se tornou fundamental ao estudo do tema, formulou a teoria da propriedade como uma função, causando a transformação da noção jurídica da propriedade, que teria se socializado:

Sin embargo, la propiedad es una institución jurídica que se ha formado para responder a una necesidad económica, como por otra parte todas las instituciones jurídicas, y que evoluciona necesariamente con las necesidades económicas mismas. Ahora bien, en nuestras sociedades modernas la necesidad económica, a la cual ha venido a responder la propiedad institución jurídica, se transforma profundamente; por consiguiente, la propiedad como institución jurídica debe transformarse también. La evolución se realiza igualmente aquí en el sentido socialista. Está también deteminada por una interdependencia cada vez más estrecha de los diferentes elementos sociales. De ahí que la propiedad, par decirlo así, se socialice. Esto no significa que llegue a ser colectiva en el sentido de las doctrinas colectivistas; pero significa dos cosas: primeramente, que la propiedad individual deja de ser un derecho del individuo, para convertirse en una función social; y en segundo lugar, que los casos de afectación de riqueza a las colectividades, que jurídicamente deben ser protegidas, son cada día más numerosos. ${ }^{33}$ 
Antes destaque-se, entretanto, que o fenômeno da constitucionalização da função social da propriedade se originou com as Constituições do México de 1917 e da Alemanha de 1919 (Constituição de Weimar). Apesar de a Constituição do México ter sido a primeira de todas, a de Weimar veio a se tornar paradigma do constitucionalismo do primeiro pós-guerra do século $X X$, dada a importância que assumira e às circunstâncias de seu surgimento, resultado da quebra do antigo regime e da implantação de uma República Social na Alemanha. ${ }^{34}$

Segundo Pilati:

A função social redimensiona 0 individual e o próprio conceito de propriedade, em termos estruturais. Quando se fala em função social, não é da propriedade comum codificada que se está a falar; trata-se de propriedade especial constitucionalizada. Propriedade que não se restringe ao gênero bens corpóreos e sim, em sentido amplo, estende-se a todo poder econômico exercido erga omnes, ou seja, a toda disposição, uso ou gozo proprietário que atinja o interesse coletivo na sua dimensão constitucional fundamental. ${ }^{35}$

Vale dizer que se trata também da propriedade intelectual e do capital financeiro, e de qualquer situação semelhante que apresente tangência com interesses coletivos, e não somente as propriedades imóveis urbanas e rurais. Assim, a proteção jurídica da função social sai da esfera exclusiva do voluntarismo estatal e passa para a esfera de tutela efetiva pela sociedade, personalizada como ator social e sujeito coletivo de direitos. ${ }^{36}$

No entanto, é necessário examinar e definir o perfil atual da função social, tanto em termos teóricos como na legislação e na jurisprudência brasileiras, projetando-se, desta maneira, a uma perspectiva de sua eficácia e de sua efetividade. $^{37}$

Na sequência destes considerandos, a propriedade deixa de ser vista como um direito individual, de caráter absoluto, estando vinculada à sua função social. Evidencia-se, portanto, uma nova concepção do Direito de Propriedade, tanto que hoje perdeu suas mais antigas características que, frente ao desenvolvimento de novas correntes do pensamento político e social, vêm sendo substituídas por uma concepção dinâmica, mais humana e de denso conteúdo social.

Com o desfazimento da moldura individualista, a concepção de propriedade vem ganhando ares coletivos nos mais diversos ordenamentos jurídicos do globo, sendo expressamente recepcionada pela Constituição de 1988 , no artigo $5^{\circ}$, que trata das garantias e direitos individuais em seu inciso XXIII, afirmação positiva de que "a propriedade atenderá sua função social".

De acordo com Martins-Costa, atualmente, entende-se como "direito de propriedade" um complexo de situações, deveres, obrigações e ônus jurídicos, a par de direitos subjetivos e poderes formativos que se opõem em perspectiva escalonada. A propriedade privada deixou de configurar um direito individual para constituir uma situação complexa em que também estão presentes deveres e obrigações de caráter social. Neste aspecto, é a partir da propriedade que se exterioriza a função social, que passa a integrar o complexo de direitos e deveres originados do Direito de Propriedade, alterando a idéia individualista. ${ }^{38}$ 
No rastro das novas tendências, o Código Civil, amparado pela Lei Maior e contrariamente ao Estatuto Civilista de 1916, que fora moldado de acordo com as linhas mestras do individualismo, herança da concepção napoleônica, deixou de encarar a propriedade privada, tanto a rural como a urbana, como um direito pleno do proprietário, e sim como uma faculdade, deixando de ser um direito absoluto para ser entendido dentro de um contexto social. Essa visão se intensificou após a crescente urbanização das sociedades ocidentais, quando os direitos de vizinhança passaram a impor limites ao exercício do direito de propriedade e a sustentar o desenvolvimento da teoria do abuso de direito. ${ }^{39}$ Sobre este tema, Fachin afirma que "a expressão função social corresponde a limitações em sentido largo impostas ao conteúdo do Direito de Propriedade". 40

O parágrafo único do artigo 1.228 da novel Codificação regulou a matéria de modo parcimonioso ao programatizar que: "O direito de propriedade deve ser exercido em consonância com suas finalidades econômicas e sociais e de modo que sejam preservados, de conformidade com o estabelecido em lei especial, a flora, a fauna, as belezas naturais, o equilíbrio ecológico e o patrimônio histórico e artístico, bem como evitada a poluição do ar e das águas"." 41

Antes, o denominado Estatuto da Cidade (Lei $n^{\circ}$ 10.257, de 10 de julho de 2001), de certo modo antecipava a regulamentação do tema, sendo inovador dispositivo legislativo no intuito de tornar mais humanas as cidades brasileiras, que vai ao encontro do princípio da função social da propriedade do inciso XXIII do artigo $5^{\circ}$ da Constituição Federal. Novamente aqui se valorou sobremaneira a função hermenêutica, para deixar à análise do caso concreto se ocorrente ou não que, aliás, como antes já se destacou, é uma linha mestra do atual Digesto Civil, através das cláusulas gerais (abertas), como anteriormente enfatizado.

Outra previsão muito noticiada e comentada é a denominada restrição ao condômino antissocial (artigo 1.337), para cuja análise, mesmo que rapidamente por ser meramente ilustrativa, se parte agora.

Com o advento da Lei $\mathrm{n}^{\circ}$ 10.406, de 2002, não só a propriedade teve disciplinada uma nova concepção, como também a fração desta, com algumas mudanças importantes para a vida em condomínio, especialmente estabelecendo maior rigorismo na tentativa de punir o denominado condômino antissocial. 0 vigente Código insere como novidade a multa ao condômino de comportamento nocivo à coletividade, considerado assim aquele problemático, inconveniente, e ao desajustado contumaz, que se mostra incapaz de viver na sociedade condominial.

Desta forma, a propriedade deve satisfazer os interesses da coletividade, destinando-se ao cumprimento de sua função social, de acordo com a previsão constitucional atual. Assim, a propriedade que não cumpre sua função social não terá garantia constitucional, sendo que seu proprietário não deverá ter assegurada defesa nas ações possessórias. "À propriedade, nessa hipótese, lhe falta justificativa, aqui apreendida numa dimensão ética, social e jurídica". ${ }^{2}$

Considerando a existência de conflitos entre direitos e interesses individuais e coletivos, devem-se levar em conta alguns princípios constitucionais indispensáveis 
na superação de tais impasses, os quais serão tratados a seguir.

\section{ALGUNS ASPECTOS FUNDAMENTAIS RELACIONADOS AOS PRINCÍPIOS CONSTITUCIONAIS}

No contexto da interpretação dada por aqueles que trabalham na perspectiva da "repersonalização" e da "constitucionalização" do Direito Civil, fica evidente que, quando verificada a incompatibilidade da utilização da propriedade individual frente ao interesse social, se deve analisar o caso concreto perante a Constituição Federal, utilizando especialmente a ponderação. ${ }^{43}$ Para superar o impasse entre o interesse individual e o coletivo, faz-se então necessário o uso do critério hermenêutico através do qual o intérprete precisa se inclinar pela possibilidade que melhor otimize os princípios constitucionais. Dentre eles, o princípio da proporcionalidade, amplamente adotado pelos teóricos da interpretação constitucional e pelas cortes constitucionais, na consolidação do balanceamento ou da ponderação de direitos e interesses em conflito.

Segundo Alexy, os princípios dos direitos constitucionais aplicam-se amplamente em todas as áreas do Direito, e graças a esta aplicabilidade os direitos constitucionais se tornam onipresentes. Portanto, princípios são normas que requerem que algo seja realizado na maior medida das possibilidades fáticas e jurídicas existentes. No que diz respeito ao princípio da proporcionalidade, 0 autor destaca que ele está amplamente relacionado ao princípio da adequação e ao princípio da necessidade. ${ }^{44}$ A necessidade de ponderação, antes citada, é uma significativa técnica hermenêutica, significando, para seu principal idealizador, que "o otimizar relativamente a um princípio colidente de outra coisa não consiste que do ponderar". 45

Assim, a mera produtividade econômica não resguarda a propriedade se não forem atendidos os valores extrapatrimoniais que compõem a tábua axiológica da Constituição. Da mesma maneira, o latifúndio utilizado para fins especulativos, ainda que produtor de alguma riqueza, estará descumprindo sua função social, por desrespeitar as situações jurídicas existenciais e sociais nas quais se insere.

No ordenamento constitucional, o tema ganha dimensão e importância ao ser definido como garantia fundamental nos termos dos incisos XXII e XXIII do artigo 5은 da Carta Magna, que determinam seja garantido 0 direito de propriedade, açambarcada na ideia de que a propriedade cumprirá sua função social, respectivamente, sob o enfoque de um direito individual. Entrementes, já 0 artigo 170 do texto constitucional enuncia a função social privada como um princípio da ordem econômica do Estado, interpretada não mais no ponto de vista individual, mas sobre uma dimensão coletiva, universal.

Neste sentido, o não-cumprimento da função social da propriedade é apontado como caracterizador de abuso de direito e violação dos direitos humanos fundamentais à moradia e à alimentação de não-proprietários, reforçando a vinculação direta existente entre o direito de propriedade e a concretização dos direitos humanos fundamentais. ${ }^{46}$

Este é o contexto da função social da propriedade que se projeta numa 
república participativa com seu desenvolvimento fundamentado na sustentabilidade, em prol da coletividade, da segurança e do bem de todos, através de normas de ordem pública e de interesse social.

A partir da contextualização doutrinária de alguns aspectos relacionados à "constitucionalização" e "repersonalização" do Direito Civil, é fundamental comprovar se os Tribunais brasileiros estão adotando, ou não, estas correntes em ações que discutem Direitos Reais no Brasil.

$\mathrm{Na}$ continuação, a linha de chegada destas breves provocações, com o relato do que se encontrou nos Tribunais antes citados sobre o tema em enfoque.

\section{PERSPECTIVAS DA “CONSTITUCIONALIZAÇÃO" E DA “REPERSONALIZAÇÃO” EM ALGUNS TRIBUNAIS BRASILEIROS, VOLTADAS AOS DIREITOS REAIS}

A pesquisa proposta tem por objetivo confirmar ou não a plena aplicação, nos Tribunais pesquisados, das sustentações teóricas denominadas "constitucionalização" e "repersonalização" dos Direitos Reais em nosso país, e ainda se sua não-adoção não significaria o risco de tornar o texto constitucional em "letra morta". ${ }^{47}$ Pesa, ainda, a formação jurídica ${ }^{48}$ voltada a um modelo liberalindividualista de Direito e a uma sociedade onde, no correto entender de Ricoeur, "há ausência de um projeto coletivo claro". 49

Para verificar a utilização, ou não, desta nova perspectiva de interpretação nos Tribunais brasileiros, realizou-se pesquisa jurisprudencial via correspondência eletrônica e diretamente nas páginas eletrônicas dos Tribunais, visto que só se obteve resposta do primeiro tipo de contato por quatro Tribunais, quais sejam: Superior Tribunal de Justiça, Tribunal de Justiça de Pernambuco, Tribunal de Justiça do Rio Grande do Sul e Tribunal de Justiça de São Paulo. Os dois últimos responderam que a pesquisa de jurisprudência está disponível em suas páginas eletrônicas, em local próprio. Além disso, pesquisou-se em dois livros que destacam os principais julgados do Superior Tribunal de Justiça ${ }^{50}$ e do Supremo Tribunal Federal $^{51}$ em 2007, mas em ambos não se encontrou julgados que se refiram à “constitucionalização" ou "repersonalização" do Direito Civil.

Na sequência, ilustra-se com algumas dessas decisões.

\subsection{Supremo Tribunal Federal}

Nesta pesquisa, pouco foi encontrado em relação à "constitucionalização" e "repersonalização" voltadas aos Direitos Reais nos arquivos do STF, à exceção de algumas decisões que se verificam neste sentido. ${ }^{52}$

É necessário destacar importante decisão da Excelsa Corte relacionada ao direito de propriedade e à função social da propriedade, e que leva em consideração a "constitucionalização", nos seguintes termos: 
social que lhe é inerente (CF, art. 5, XXIII), legitimar-se-á a intervenção estatal na esfera dominial privada, observados, contudo, para esse efeito, os limites, as formas e os procedimentos fixados na própria Constituição da República. $O$ acesso à terra, a solução dos conflitos sociais, 0 aproveitamento racional e adequado do imóvel rural, a utilização apropriada dos recursos naturais disponíveis e a presenvação do meio ambiente constituem elementos de realização da função social da propriedade. ${ }^{53}$

É possível, ainda, observar a preocupação com os princípios constitucionais em algumas decisões recentes do Tribunal referido, como a dignidade da pessoa humana, quando do pronunciamento de decisão que deu origem a Súmula Vinculante $n^{\circ} 11$, que regulamenta o uso de algemas, em 13 de agosto de 2008, na qual a Corte Máxima vincou bem sua posição. ${ }^{54}$

Vê-se, desta forma, o novo protagonismo do Supremo Tribunal Federal. ${ }^{55}$ No seguimento, breve análise do tema no Superior Tribunal de Justiça.

\subsection{Superior Tribunal de Justiça}

O Superior Tribunal de Justiça enviou resposta via correspondência eletrônica, sendo que os tópicos para pesquisa foram: Constitucionalização do Direito Civil, Dignidade da Pessoa Humana, Repersonalização do Direito Civil e Função social da propriedade, todos ligados aos Direitos Reais. Nada encontraram com referência aos tópicos pesquisados e aos Direitos Reais. No entanto, enviaram um julgado que destaca a questão da constitucionalização do Direito Civil, mas não ligada aos Direitos Reais. ${ }^{56}$

Apesar disso, deve-se salientar a aprovação de nova Súmula, a de número 364, do Superior Tribunal de Justiça, que expande a proteção dada ao bem de família a pessoas solteiras, separadas e viúvas:

\footnotetext{
Nova Súmula, a de número 364, aprovada pela Corte Especial amplia os casos em que se pode usar a proteção do Bem de Família. Criado pela Lei no 8.009, de 1990, o Bem de Família é definido como o imóvel residencial do casal ou unidade familiar que se torna impenhorável para pagamento de dívida. $O$ projeto 740 , que deu origem à nova Súmula, foi relatado pela Ministra Eliana Calmon e estendeu a proteção contra a penhora para imóveis pertencentes a solteiros, viúvos ou descasados. Entre os precedentes da Súmula 364 estão os Recursos Especiais (Resp) 139.012, $450.989,57.606$ e $159.851 .^{57}$
}

Observe-se, no entanto, que a consagração deste entendimento, embora louvável, demorou 20 anos da edição da vigente Constituição Federal, em que pese a boa fundamentação teórica neste mesmo prumo construída por tantos doutrinadores. Nos Tribunais estaduais, infelizmente, esta "timidez jurisprudencial" não é diferente, como se verá logo.

\subsection{Tribunais estaduais}

A pesquisa à jurisprudência dos Tribunais Estaduais foi realizada com os mesmos tópicos referidos no item antecedente. No que segue há menção expressa a algumas decisões que foram encontradas. 


\title{
3.3.1 Tribunal do Estado do Rio Grande do Sul
}

Verificou-se que o Tribunal gaúcho tem decidido em vários julgados levando em consideração os princípios constitucionais. Neste sentido, vale destacar o que a Desembargadora Mara Larsen Chechi ressalta em seu voto no Agravo de Instrumento $\mathrm{n}^{\circ}$ 70016021024, que diz: ' $\mathrm{O}$ direito de propriedade, conquanto consagrado como direito fundamental no art. $5^{\circ}$, caput, da Constituição Federal, não é absoluto. Sofre diversas limitações constitucionais, entre elas a função social da propriedade, a proteção ao meio ambiente, o direito à saúde e a política de desenvolvimento urbano". 58

Em seu voto na Apelação Cível n 70015377393 , o Relator e Desembargador Glênio José Wasserstein Hekman destaca que:

Correta a sentença hostilizada, que entendeu: 'Com efeito, não há princípio constitucional algum que obstaculize o direito do adquirente de tomar posse da coisa adquirida. Muito antes pelo contrário, a Carta Magna consagra tal faculdade' (fl. 70). Neste sentido, tenho que aplicável o disposto no artigo $5^{\circ}$, caput, da Constituição Federal/88, norma definidora dos direitos e garantias fundamentais de aplicabilidade imediata. ${ }^{59}$

\subsubsection{Tribunal de Justiça de Minas Gerais}

$\mathrm{Na}$ pesquisa feita nesta Corte pode-se constatar a referência à constitucionalização do Direito Civil. Consolidando tal posicionamento, destaca-se a seguir:

\begin{abstract}
EMENTA: Reintegração de posse - Passagem forçada - Acesso à via pública - Fundamentos. $O$ direito à passagem forçada tem por fundamento, a um só tempo, a solidariedade que deve presidir as relações de vizinhança e a necessidade econômica de se aproveitar devidamente o prédio encravado. $O$ interesse social exige se estabeleça passagem para que 0 imóvel não se torne improdutivo. No caso dos autos, não permitir a passagem do autor por tal caminho irá onerá-lo substancialmente no transporte de sua colheita por um caminho mais longo. V.v. A passagem forçada está ligada à noção de necessidade, pois implica em verdadeira limitação dos direitos reais existentes sobre o imóvel onerado, que só se justifica na hipótese de encontrar-se o prédio sem saída para a via pública, fonte ou porto. A mera comodidade mediante o encurtamento do acesso à vida pública não confere o direito de passagem. Apelo desprovido. ${ }^{60}$
\end{abstract}

No acórdão, o Desembargador Rogério Medeiros destaca a constitucionalização do Direito infraconstitucional. Iniciada na Alemanha e na Itália, a teoria irradiou-se posteriormente por países de democratização mais tardia, como Portugal, Espanha e Brasil. Ressalta que:

O Código Civil certamente perdeu a centralidade de outrora. O papel unificador do sistema, tanto em seus aspectos mais tradicionalmente civilísticos quanto naqueles de relevância publicista, é desempenhado de maneira cada vez mais incisiva pelo Texto Constitucional. Falar de descodificação relativamente ao Código vigente não implica absolutamente a perda do fundamento unitário do ordenamento, de modo a propor sua fragmentação em diversos microordenamentos e em diversos microssistemas, com ausência de um desenho global. Desenho que, se não aparece no plano legislativo, deve ser identificado no constante e tenaz 
trabalho do intérprete, orientado a detectar os princípios constantes na legislação chamada especial, reconduzindo-os à unidade, mesmo do ponto de vista da sua legitimidade. $O$ respeito aos valores e aos princípios fundamentais da República representa a passagem essencial para estabelecer uma correta e rigorosa relação entre poder do Estado e poder dos grupos, entre maioria e minoria, entre poder econômico e os direitos dos marginalizados, dos mais desfavorecidos. ${ }^{61}$

O Desembargador Rogério Medeiros diz que a questão não reside na disposição topográfica (códigos, leis especiais), mas na correta individualização dos problemas. A tais problemas será necessário dar uma resposta, procurando-a no sistema como um todo, sem apego à preconceituosa premissa do caráter residual do Código e, por outro lado, sem desatenções às leis cada vez mais numerosas e fragmentadas.

Nos Tribunais estaduais de Santa Catarina, Paraná, São Paulo, Rio de Janeiro, Bahia e Pernambuco não foram encontrados julgados relacionados à "repersonalização" ou "constitucionalização" do Direito Civil no que se refere aos Direitos Reais.

Destaque-se que, na busca em páginas eletrônicas das Cortes citadas, se utilizou as duas expressões como critério de busca. No entanto, foi possível perceber que o princípio da dignidade da pessoa humana está presente em diversos julgados desses Tribunais. ${ }^{62}$ Ainda, no Tribunal fluminense há uma decisão relevante em ação que discute proteção ao bem de família de fiador de locação de imóveis. ${ }^{63}$ Mesmo reconhecendo o entendimento da Corte Excelsa e dos demais Tribunais, o acórdão deixa claro, já na ementa, que a penhorabilidade do bem de família do fiador de contrato de locação, permitida pelo inciso VII do artigo $3^{\circ}$ da Lei $n^{\circ}$ 8.009, fere 0 artigo $6^{\circ}$ da Carta Magna, "principalmente diante das peculiaridades, dentre elas quando envolve aspectos de ordem social e desigualdade entre um dos contratantes". ${ }^{4}$

No voto, para cuja leitura se remete, o relator sustenta que "o direito do locador consiste, exclusivamente, em um direito de crédito, sendo certo que o prejuízo maior que sofrerá consistirá na redução ou eliminação de seu lucro no investimento que realizou, sem as cautelas adequadas". ${ }^{65} \mathrm{Em}$ sua fundamentação, 0 julgador ainda refere que geralmente os fiadores são pessoas desprovidas de maior cultura e ainda vinculados emocionalmente aos contratantes que afiançam, e também que somente poderiam eventualmente ser responsabilizados pelo débito, além dos cinco critérios que lá propõe, a partir da data que tomarem ciência inequívoca dos atrasos, concluindo ser 'fundamental que inexista qualquer vínculo de subordinação ou dependência entre locatário e fiador, visto que muitas são as vezes em que o primeiro se vale dessa condição para inviabilizar uma recusa por parte do segundo". 66

Laborando com o aval de opinião da grandeza de Jürgen Habermas, pode-se reafirmar, mais uma vez e sempre, que "os destinatários do Direito também devem entender-se como seus próprios autores". ${ }^{67}$

O caminho a seguir ainda é longo, como se reiterará nas coclusões. 


\section{CONCLUSÕES}

No início do presente escrito salientou-se que o principal objetivo era descrever a utilização, ou não, no Poder Judiciário brasileiro, das fundamentações teóricas denominadas "constitucionalização" e "repersonalização" do Direito Civil, especificamente em casos concretos onde se discutem Direitos Reais.

Através do estudo realizado, foi possível verificar que os Direitos Reais passaram por significativa evolução até chegar ao século XXI, com caráter menos individualista e mais voltado à coletividade, sendo que a Constituição Federal de 1988 teve papel determinante através dos princípios fundamentais que dela emanam.

Da mesma forma, percebeu-se que nos dias atuais há uma nova dimensão do Direito Privado, que busca atender à justiça social, respeitando os direitos fundamentais consagrados na Constituição Federal, dentre eles a dignidade da pessoa humana e o direito à moradia, relacionado diretamente à função social da propriedade.

Em relação à "repersonalização" e "constitucionalização" do Direito Civil, no que diz respeito aos Direitos Reais e aos julgados dos Tribunais brasileiros, embora tenha como campo somente as Corte sindicadas e as possíveis decisões às quais não se teve acesso, percebe-se nitidamente que ainda é tímida a utilização, no sistema judiciário pátrio, de tal fundamentação teórica.

No entanto, a constitucionalização do Direito Civil é um processo que vem ficando mais intenso. Principalmente a partir de 1988, e mais notadamente nos últimos cinco ou dez anos, a Constituição passou a desfrutar já não apenas da supremacia formal que sempre teve, mas também de uma supremacia substancial, axiológica, potencializada pela abertura do sistema jurídico e pela normatividade de seus princípios. Ao exibir, desta forma, força normativa sem precedente, a Constituição ingressou na paisagem jurídica do país e no discurso dos operadores jurídicos.

Neste sentido, é necessário ter firme a necessidade de enfrentar desafios, romper determinados conceitos e pensamentos absolutos e considerar que a mudança de atitude é essencial no sentido de que 0 manejo das categorias fundamentais da Constituição Federal é imprescindível. ${ }^{68}$

O caminho é longo, e passa necessariamente pelo ensino do Direito nos mais variados níveis, a começar pela graduação. Para já, entretanto, bastam estas linhas, como se disse desde o princípio, com a pretensão única de provocar o debate.

Como dito no título deste artigo, a realidade mostra os espinhos, mas eles são obstáculos necessários para que um dia se alcance a flor... 
TO SAY THAT WE DO NOT TALKED ABOUT THORNS: THE CIVIL LAW CONSTITUCIONALIZATION AND IT'S HARD CONCRETIZATION IN THE IDEA ABOUT RE-PERSONALIZATION IN REAL STATE ACTIONS IN BRAZILIAN'S COURTS

\begin{abstract}
This article proposes to briefly analyze the theoretical construction of the explanatory stream so called "constitutionalization of Civil Law", and within it the ideia of "repersonalization", and the occurrence or no-occurrence of these ideias in the formulation of decisions related to Real Rights in some Brazilian Courts.
\end{abstract}

Keywords: Real Rights. Law of Property. Social function of Property. Constitutionalization. Repersonalization. Constitutional Principles.

\title{
NOTAS
}

1 Pesquisa financiada pela Universidade Luterana do Brasil e vinculada ao Grupo de Pesquisa Constitucionalização do Direito Civil e Hermenêutica Jurídica, cujo líder é o primeiro autor.

2 Advogado, Mestre e Doutor em Direito pela Unisinos; professor dos Cursos de Direito da Universidade Luterana do Brasil - Ulbra (Gravataí/RS), do Centro Universitário La Salle - Unilasalle (Canoas/RS) em nível de graduação e pós-graduação (Mestrado em Memória Social e Bens Culturais); e do Centro Universitário Ritter dos Reis - Uniritter, em nível de Especialização. Membro da Associação Brasileira de Direito Autoral - ABDA; da Associação Portuguesa de Direito Intelectual - APDI e da Comissão Especial de Propriedade Intelectual da Ordem dos Advogados do Brasil, Secção Rio Grande do Sul.

Acadêmica do Curso de Direito da Ulbra Gravataí. Bolsista voluntária.

ALLENDE, Isabel. Zorro: começa a lenda. Rio de Janeiro: Bertrand Brasil, 2006, p. 35.

Função social esta que não fica adstrita ao direito de propriedade, mas que abarca todo o Direito, podendose falar, sem sombra de dúvidas, em função social "do Direito". No âmbito do Direito Civil destacam-se especialmente os estudos recentes sobre a função social do contrato. Dentre os tantos enfrentamentos de qualidade do tema, enfatiza-se CAGLIARI, Cláudia Taís; REIS, Jorge Renato dos. A função social dos contratos como instrumento de efetivação dos direitos fundamentais nas relações interprivadas. In GORCZEVISKI, Clóvis; REIS, Jorge Renato dos. Direitos fundamentais sociais como paradigmas de uma sociedade fraterna: Constitucionalismo contemporâneo. Santa Cruz do Sul: IPR, 2008, p. 13-39.

6 MARTINS-COSTA, Judith (Org.). A reconstrução do Direito Privado: reflexos dos princípios, diretrizes e direitos fundamentais constitucionais no Direito Privado. São Paulo: Revista dos Tribunais, 2002. Introdução, p. 15.

7 ALVES, Leonardo Barreto Moreira. A teoria do umbral do acesso ao Direito Civil como complemento à teoria do estatuto jurídico do patrimônio mínimo. Jus Navigandi, Teresina, v. 11, n. 1.535, 14 set. 2007. Disponível em: <http://jus2.uol.com.br/doutrina/texto.asp?id=10406>. Acesso em: 12 nov. 2007.

8 TEPEDINO, Gustavo. Temas de Direito Civil. 2. ed. Rio de Janeiro: Renovar, 2001, p. 2.

9 MARTINS-COSTA, 2992, p. 13.

10 ALVES, 14 set. 2007, p. 4.

11 FACHIN, Luiz Edson. Questões do Direito Civil brasileiro contemporâneo. Rio de Janeiro: Renovar, 2008, p.53.

12 TEPEDINO, 2001, p. 2.

13 A dignidade da pessoa humana é, na sempre autorizada palavra de Peter Häberle, a grundnorm do ordenamento jurídico. HÄBERLE, Peter. La dignidad del hombre como fundamento de la comunidad estatal. In SEGADO, Francisco Fernández. Dignidad de la persona, derechos fundamentales, justitia constitucional. Madrid: Dykinson, 2008, p. 175-237. 
14 HANNA, Munira. Repersonalização e constitucionalização: superação do paradigma patrimonialista. Revista da Ajuris, Porto Alegre, v. 32, n. 98, p. 223-224, 2005.

15 ARONNE, Ricardo. Propriedade e Domínio: reexame sistemático das noções nucleares de Direitos Reais. Rio de Janeiro: Renovar, 1999, p. 422.

16 LÔBO, Paulo Luiz Netto. Constitucionalização do Direito Civil. Revista de Informação Legislativa, Brasília: Senado Federal, n. 141, p. 99, 1999. Embora haja aqueles, como o jurista espanhol Jose Luiz de los Mozos, como noticia Marco Fábio Morsello, que sustentam um retorno à velha forma, afirmando que "para interpretar a Constituição necessitaremos do Direito Civil”. MORSELLO, Marco Fábio. Direito Civil Constitucional e o Direito de Propriedade no Brasil e no Direito Comparado. Revista da Pós-Graduação da Faculdade de Direito da Universidade de São Paulo, São Paulo, Síntese, v. 2, p. 95-96, 2000.

17 PERLINGIERI, Pietro. Perfis do Direito Civil. 2. ed. Rio de Janeiro: Renovar, 2002, p. 4.

18 ARONNE, Ricardo. Por uma nova hermenêutica dos direitos reais limitados: das raízes aos fundamentos contemporâneos. Rio de Janeiro: Renovar, 2001, p. 88.

19 FACHIN, Luiz Edson. Teoria Crítica do Direito Civil. 2. ed. Rio de Janeiro: Renovar, 2003, p.78.

20 Neste particular, interessante afirmativa de Antônio Carlos de Araújo Cintra, Ada Pellegrini Grinover e Cândido Rangel Dinamarco: “A absoluta igualdade jurídica não pode, contudo, eliminar a desigualdade econômica; por isso, do primitivo conceito de igualdade, formal e negativa (a lei não deve estabelecer qualquer diferença entre os indivíduos), clamou-se pela passagem à igualdade substancial. E hoje,, na conceituação positiva da isonomia (iguais oportunidades para todos, a serem propiciadas pelo Estado), realça-se o conceito realista, que pugna pela igualdade proporcional, a qual significa, em síntese, tratamento igual aos substancialmente iguais". A aparente quebra do princípio da isonomia, submete-se ao princípio da igualdade real e proporcional, a qual impõe tratamento desigual aos desiguais, para que sejam supridas as diferenças e que a igualdade substancial seja atingida. (CINTRA, Carlos de Araújo; GRINOVER, Ada Pellegrini; DINAMARCO, Cândido Rangel. Teoria Geral do Processo. São Paulo: Malheiros, 2007, p. 5960).

21 TEPEDINO, Gustavo. Problemas de Direito Civil-Constitucional. Rio de Janeiro: Renovar, 2000, p. 12-13.

22 LÔBO, 1999, p. 99.

23 FACHIN, 2003, p. 77.

24 BARROSO, Luís Roberto. Neoconstitucionalismo e constitucionalização do Direito. Revista do Tribunal de Contas do Estado de Minas Gerais. Belo Horizonte, v. 65, p. 28, out./dez. 2007. Como já se disse em outro texto (ADOLFO, Luiz Gonzaga Silva; SANTOS, Liziane da Silva. Por quem os sinos dobram: os 20 anos da Constituição Federal de 1988 e a centralidade da dignidade da pessoa humana. Destaque Jurídico: revista de estudos jurídicos, Gravataí, ULBRA, v. 7, n. 7, p. 17, 2008), é preciso superar a confusão que boa parte dos escritores nacionais faz entre normas e regras, sem sequer indagar de forma adequada de qual se trata, a partir da ideia já consagrada de que as normas são compostas de regras e princípios. Assim, em Dworkin, "a diferença entre princípios jurídicos e regras jurídicas é de natureza lógica. Os dois conjuntos de padrões apontam para decisões particulares acerca da obrigação jurídica em circunstâncias específicas, mas distinguem-se quanto à natureza da orientação que oferecem. As regras são aplicáveis à maneira do tudo-ounada. Dados os fatos que uma regra estipula, então ou a regra é válida, e neste caso a resposta que ela fornece deve ser aceita, ou não é válida, e neste caso em nada contribui para a decisão" (DWORKIN, Ronald. Levando os direitos a sério. São Paulo: Martins Fontes, 2002, p. 39). Alexy, antes de enfrentar a possibilidade de colisão entre princípios e sua melhor forma de solução, faz uma distinção entre regras e princípios, concluindo que "princípios são normas que ordenam que algo seja realizado em uma medida tão ampla quanto possível relativamente a possibilidades fáticas ou jurídicas” (ALEXY, Robert. Colisão de Direitos Fundamentais e realização de Direitos Fundamentais no Estado de Direito Democrático. Revista de Direito Administrativo, Rio de Janeiro, Renovar, n. 217, p. 74-5, jul./set. 1999). Os princípios, nesta sustentação, são mandatos de otimização caracterizados pela possibilidade de cumprimento em diferentes graus e, ainda, a medida de sua observância não somente depende das possibilidades reais, como também das jurídicas, de modo que "el ámbito de las posibilidades jurídicas es determinado por los principios y reglas opuestos". Por seu turno, as regras são normas que somente devem ser cumpridas ou não. Ou seja, sendo válida a regra, deve ser feito exatamente o que ela exige, nem mais nem menos. Portanto, as regras contêm determinações no âmbito do fática e juridicamente possível, e "esto significa que la diferencia entre reglas y principios es cualitativa y no de grado", e que "toda norma es o bien una regla o un principio" (Idem. Teoría de los Derechos Fundamentales. Madrid: Centro de Estudios Constitucionales, 1997, p. 86-7). Outro para o qual se remete, nesta particularidade, pela excelência de sua obra, é especialmente Pulido em ?Cuándo una norma es una regla y cuándo una norma es un principio? (PULIDO, Carlos Bernal. El principio de proporcionalidad y los derechos fundamentales. 3. ed. Madrid: Centro de Estudios Políticos y Constitucionales, 2007, p. 590-3).

25 HANNA, 2005, p. 224. Barroso destaca que o marco filosófico do novo Direito Constitucional é o póspositivismo, sendo que o debate a respeito de sua caracterização situa-se na confluência do jusnaturalismo e 
do positivismo, duas grandes correntes de pensamento que oferecem paradigmas opostos para o Direito. Considera que, embora opostos, por vezes, complementares. "O jusnaturalismo moderno, desenvolvido a partir do século XVI, aproximou a lei da razão e transformou-se na filosofia natural do Direito. Fundado na crença em princípios de justiça universalmente válidos, foi o combustível das revoluções liberais e chegou ao apogeu com as constituições escritas e as codificações. Considerado metafísico e anti-científico, o Direito natural foi empurrado para a margem da história pela ascensão do positivismo jurídico, no final do século XIX. [...] A superação histórica do jusnaturalismo e o fracasso político do positivismo abriram caminho para um conjunto amplo e ainda inacabado de reflexões acerca do Direito, sua função social e interpretação" (BARROSO, p. 22, out./dez. 2007). ADOLFO, Luiz Gonzaga Silva. Obras privadas, beneficios coletivos: a dimensão pública do Direito Autoral na sociedade da informação. Porto Alegre: Sergio Antonio Fabris, 2008, p. 42. FERRAJOLI, Luigi. Democracia y garantismo. Madrid: Trotta, 2008, p. 298.

28 MARTINS-COSTA, Judith Hofmeister. O Direito Privado como um "Sistema em Construção". Revista da Faculdade de Direito da UFRGS, Porto Alegre, v. 15, p. 130, 1998. PERLINGIERI, 2002, p. 27.

30 TEPEDINO, 2000, p. 10.

31 MELO, Marco Aurélio Bezerra de. Novo Código Civil anotado: Direito das Coisas. Rio de Janeiro: Lumen Juris, 2003. v. V, p. 40.

32 TUTIKIAN, Cristiano. Sistema e Codificação: o Código Civil e as cláusulas gerais. In: ARONNE, Ricardo (Org.). Estudos de Direito Civil-Constitucional. Porto Alegre: Livraria do Advogado, 2004. V. 1, p. 76. DUGUIT, León. Las transformaciones generales del Derecho Privado desde el Código de Napoleón. 2. ed. espanhola. Tradução de Carlos G. Pousada. Madrid: Francisco Beltran Libreria, 1912, p. 168-169. PILATI, José Isaac. A função social da propriedade a partir da Constituição de 1988: o resgate da dimensão coletiva. Destaque Jurídico: revista de estudos jurídicos, Gravataí, ULBRA, v. 7, n. 7. p. 204-205, 2008. Idem, p. 204.

37 Ibidem, p. 206.

38 MARTINS-COSTA, Judith. Diretrizes teóricas do Novo Código Civil brasileiro. São Paulo: Saraiva, 2002, p. 150.

39 SILVA FILHO, José Moreira da. Transformações jurídicas nas relações privadas. In: ROCHA, Leonel Severo; STRECK, Lenio Luiz (Org.). Anuário do Programa de Pós-Graduação em Direito. São Leopoldo: Unisinos, 2003, p. 173.

FACHIN, Luiz Edson. A função da posse e da propriedade contemporânea (uma perspectiva da usucapião imobiliária rural). Porto Alegre: Fabris, 1998, p. 19.

41 BRASIL. Código Civil. Lei no 10.406, de 10 de janeiro de 2001.

42 FACHIN, 2008, p. 58.

43 Não são poucos os autores de boa cepa que analisam a ponderação. Entre eles, remete-se para DÍEZPICAZO, Luis María. Sistema de Derechos Fundamentales. 3. ed. Madrid: Thomson/Civitas, 2008.

44 ALEXY, Robert. Direitos fundamentais, balanceamento e racionalidade. Ratio Juris, Belo Horizonte, v. 16, n. 2, p. 131-140, jun. 2003.

45 Idem. Constitucionalismo Discursivo. 2. ed. Porto Alegre: Livraria do Advogado, 2008, p. 111, a quem se remete para aprofundamento. Um outro aspecto interessante enfatizado por Alexy, e para o qual já se chamou atenção, é um alerta: ao mesmo tempo que tanto tentamos superar tradições antigas e ineficazes, como o positivismo e o dogmatismo, no sentido de não construir meros "clichês", assim, embora com boa vontade, sem evolução concreta, são necessárias ações imediatas e concretas que retirem estas construções do pântano das boas intenções, mas de pouca eficácia. O mestre alemão alerta, nesta linha de foco, para as expressões de alto nível de generalidade, como "a dignidade do homem deve ser respeitada", e que diante desta realidade não devem ser usadas diretamente na justificação de uma decisão, exigindo outras premissas normativas. ALEXY, Robert. Teoria da Argumentação Jurídica: A Teoria do Discurso Racional como Teoria da Justificação Jurídica. São Paulo: Landy, 2001, p. 282. Pode-se afirmar, neste particular, agora com apoio em Giusepe Gandolfi, que haveria "una notevole aspettativa, ma um clima di incertezza". GANDOLFI, Giuseppe. Rivista di Diritto Civile. Milano, Anno LV, n. 2, p. 221-224, marzo/aprile 2008.

46 ALFONSIN, Jacques Távora. O acesso à terra como conteúdo de direitos humanos fundamentais à alimentação e à moradia. Porto Alegre: Fabris, 2003, p. 267. Na mesma sustentação, remete-se para CAMARGO, Ricardo Antônio Lucas. Os sem-teto, a especulação imobiliária e os direitos humanos. Revista da Faculdade de Direito da Universidade Federal de Minas Gerais, Belo Horizonte, n. 45, p. 373-399, jul./dez. 2004.

47 Como receia OLIVEIRA NETO, Francisco José Rodrigues de. O Poder Judiciário na concretização do Estado Democrático de Direito após 1988. In: SCAFF, Fernando Facury (Org.). Constitucionalizando direitos: 15 anos da Constituição brasileira de 1988. Rio de Janeiro: Renovar, 2003, p. 55-74. 
Dentre os bons autores e textos que enfocam o ensino jurídico no Brasil, remete-se para CUNHA, Alexandre dos Santos. Ensino jurídico e codificação civil no Brasil (1822-1916). In: TUTIKIAN, Cristiano (Org.). Olhares sobre o público e o privado. Porto Alegre: EDIPUCRS, 2008, p. 65-84. RICOEUR, Paul. Hermenêutica e Ideologias. Petrópolis: Vozes, 2008, p. 162-164.

50 FERREIRA FILHO, Roberval Rocha. Principais julgamentos do Superior Tribunal de Justiça. Salvador: Jus Podivm, 2008.

51 Idem. Principais julgamentos do Supremo Tribunal Federal. Salvador: Jus Podium, 2008.

52 BRASIL. Supremo Tribunal Federal. Tribunal Pleno. Recurso Extraordinário no 387047/SC. Relator: Min. Eros Grau. Brasília, 6 de março de 2008. Disponível em: <http://www.stf.gov.br>. Acesso em: 8 ago. 2008.

EMENTA: Recurso Extraordinário. Lei n. 3.338/89 do Município de Florianópolis/SC. Solo criado. Não configuração como tributo. Outorga onerosa do direito de criar solo. Distinção entre ônus, dever e obrigação. Função social da propriedade. Artigos 182 e 170, III da Constituição do Brasil.

1. Solo criado. Solo criado é o solo artificialmente criado pelo homem [sobre ou sob o solo natural], resultado da construção praticada em volume superior ao permitido nos limites de um coeficiente único de aproveitamento. 2. Outorga onerosa do direito de criar solo. Prestação de dar cuja satisfação afasta obstáculo ao exercício, por quem a presta, de determinada faculdade. Ato necessário. Ônus. Não há, na hipótese, obrigação. Não se trata de tributo. Não se trata de imposto. Faculdade atribuível ao proprietário de imóvel, mercê da qual se lhe permite o exercício do direito de construir acima do coeficiente único de aproveitamento adotado em determinada área, desde que satisfeita prestação de dar que consubstancia ônus. Onde não há obrigação não pode haver tributo. Distinção entre ônus, dever e obrigação e entre ato devido e ato necessário. 3. Ônus do proprietário de imóvel urbano. Instrumento próprio à política de desenvolvimento urbano, cuja execução incumbe ao Poder Público municipal, nos termos do disposto no artigo 182 da Constituição do Brasil. Instrumento voltado à correção de distorções que o crescimento urbano desordenado acarreta, à promoção do pleno desenvolvimento das funções da cidade e a dar concreção ao princípio da função social da propriedade [art. 170, III da CB]. 4. Recurso extraordinário conhecido, mas não provido.

53 Idem. Ação Direta de Inconstitucionalidade no 2.213. Relator: Min. Celso de Mello. Brasília, 4 de abril de 2004. Disponível em: <http://www.stf.gov.br/portal/constituicao/artigoBd.asp?item=31>. Acesso em: 30 ago. 2008.

54 "Só é lícito o uso de algemas em caso de resistência e de fundado receio de fuga ou de perigo à integridade física própria ou alheia, por parte do preso ou de terceiros, justificada a excepcionalidade por escrito, sob pena de responsabilidade disciplinar civil e penal do agente ou da autoridade e de nulidade da prisão ou do ato processual a que se refere, sem prejuízo da responsabilidade civil do Estado". Disponível em: $<$ http://www.stf.jus.br/arquivo/cms/jurisprudenciaSumulaVinculante/anexo/DJE_11.11.2008.pdf $>$. Acesso em: 22 jan. 2009.

55 Que se mostra lento também em outros países, a exemplo da Itália, como informa Marco Comporti: "Per suo conto, la Corte constituzionale, fedelmente interpretando l'intenzione dell'Assemblea Constituente, ha adottato una concezione nuova della proprietà secondo la formula della funzione sociale: uma proprietà, dunque, funzionalizzata agli interessi generali, cioè limitata dalle esigenze sociali nel suo contenuto di poteri e facoltà individuali; in tal modo pervenendo all'importante risultato pratico di legittimare, nella maggioranza dei casi discussi, la varia legislazionae speciale che indubbiamente, dal dopoguerra in poi, ha inciso in modo rilevante sul contenuto del diritto di proprietà (si pensi soprattutto alla legislazione sulle locazioni urbane, sugli affitti di fondi rustici, sui contratti agrari, sulle espropriazioni, ecc.)". COMPORTI, Marco. La proprietà europea e la proprietà italiana. Rivista di Diritto Civile, Milão, Casa Editrice Dott. Antonio Milani, v. LIV, n. 2, p. 195, mar./abr. 2008. O tema do "ativismo judicial", judicial activism na expressão inglesa utilizada por Riccardo Guastini, merece aprofundamento em estudo próprio. GUASTINI, Riccardo. Teoría e ideologia de la interpretación constitucional. Madrid: Trotta, 2008, p. 63-65.

56 BRASIL. Superior Tribunal de Justiça. Agravo de Instrumento no 749.108-RS (2006/0037616-5). Relator: Min. Carlos Alberto Menezes Direito. Agravante: Lojas Volpato Ltda. Advogado: Athos Gusmão Carneiro e outro(s). Agravado: Celular CRT S/A. Advogados: Oscar Luís de Morais. Rafael de Souza Santos e outro(s). Decisão. - Vistos. Lojas Volpato Ltda. interpõe agravo de instrumento contra o despacho que não admitiu recurso especial assentado em ofensa aos artigos $2^{\circ}, 3^{\circ}, 7^{\circ}$ e 70 da Lei $n^{\circ} 9.472 / 97$; $7^{\circ}$, inciso III, da

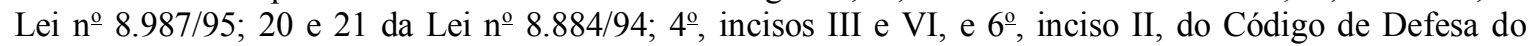
Consumidor; 924 do Código Civil; 320, 330, inciso I, 420, 454 e 473 do Código de Processo Civil. Insurgese, no apelo extremo, contra acórdão assim ementado: "Apelação Cível. Ação de Resolução Contratual. Contrato de Distribuição. Cláusula de exclusividade. Legalidade. 1 - Não há cerceamento de defesa, no caso, especialmente porque a prova é direcionada ao magistrado, a quem cabe a apreciação da necessidade ou não da prova. Comprovação dos fatos com a juntada de documentação suficiente. 2 - Com a constitucionalização do Dir eito Civil, o contrato passou a ter face pública onde deve haver solidariedade, cooperação entre os contratantes e destes em relação a terceiros, como dos terceiros em relação aos contratantes. Da natureza do contrato de distribuição a obrigação do distribuidor de revender com 
exclusividade e por conta própria o produto objeto do pacto, tendo, o referido contrato, na sua essência, a exclusividade de venda e adesão do distribuidor. Notificação da apelante à Celular CRT a fim de se desonerar da sua obrigação e comunicar o não cumprimento da cláusula de exclusividade, tendo em vista o entendimento de ilegalidade da cláusula e a notificação da TELET.

57 BRASIL. Superior Tribunal de Justiça. Súmulas. Disponível em: <http://www.stj.gov.br/portal_stj /publicacao/engine.wsp?tmp.area=398\&tmp.texto=89622>. Acesso em: 30 out. 2008. No Resp 139.012, o relator, Ministro Ari Pargendler, considerou que o imóvel de uma pessoa ainda solteira no momento em que a ação de cobrança foi proposta, e que veio a casar-se depois, era protegido contra a penhora. O Ministro considerou que, no momento da penhora, já haveria uma unidade familiar no imóvel, justamente o alvo da proteção do Bem de Família. Já em outro recurso, o 450989, o Ministro aposentado Humberto Gomes de Barros destaca que a Lei no 8.009 não visa apenas à proteção da entidade familiar, mas de um direito inerente à pessoa humana: o direito à moradia. Nesse processo, uma pessoa residia sozinha no imóvel, não tendo sido considerada protegida pela Lei em pauta. No entendimento do Ministro Relator, entretanto, a proteção deve ser estendida para esses casos. Segundo a Súmula 364, "O conceito de impenhorabilidade de bem de família abrange também o imóvel pertencente a pessoas solteiras, separadas e viúvas".

RIO GRANDE DO SUL. Tribunal de Justiça. Vigésima Segunda Câmara Cível. Agravo de Instrumento $\mathrm{n}^{\circ}$ 70016021024. Relatora: Desembargadora Mara Larsen Chechi. Porto Alegre, 26 de outubro de 2007. Disponível em: <http://www.tj.rs.gov.br>. Acesso em: 29 nov. 2007. EMENTA: Constitucional, Administrativo e Ambiental. Ação Civil Pública. Limitações constitucionais ao dir eito de propriedade. Meio ambiente. Proteção. O direito de propriedade, conquanto consagrado como direito fundamental no art. 5, caput, da Constituição Federal, não é absoluto. Só será legitimado pela ordem jurídica se estiver em harmonia com as limitações constitucionais (função social da propriedade, proteção ao meio ambiente, direito à saúde e política de desenvolvimento urbano). Agravo Provido.

Idem. Vigésima Câmara Cível. Apelação Cível no 70015377393. Relator: Des. Glênio José Wasserstein Hekman. Porto Alegre, 14 de junho de 2006. Disponível em: <http://www.tj.rs.gov.br>. Acesso em: 29 nov. 2007. EMENTA: Apelação Cível. Ação de Imissão de Posse. Arrematação. Nulidade da penhora. Preclusão. 1. Constitucionalização do Direito Civil. Tem ciência, este Julgador, da incidência e aplicabilidade das normas constitucionais em todos os ramos do Direito, especialmente, àquelas asseguradas no artigo $5^{\circ}$ da $\mathrm{CF} / 88$, garantidoras dos direitos fundamentais. Todavia, no caso posto em análise e julgamento, não há princípio constitucional que obstaculize o direito do adquirente de tomar posse do imóvel adquirido, através de carta de arrematação. No caso em análise, a ação de imissão de posse firma-se na existência de título aquisitivo carta de arrematação, devidamente registrado no Ofício Imobiliário. 2. Nulidade da penhora. Operou-se a preclusão em relação à discussão da matéria, posto que somente apreciável e passível de decisão nos autos da ação de execução de sentença. Apelo desprovido.

60 MINAS GERAIS. Tribunal de Justiça. Décima Quarta Câmara Cível. Apelação Cível no ${ }^{1}$ 1.0095.07.0014394/001. Relator: Des. Antônio de Pádua. Belo Horizonte, 14 de fevereiro de 2008. Disponível em: $<$ http://www.tjmg.gov.br>. Acesso em: 7 jun. 2008.

61 Idem, p. 7.

62 RIO DE JANEIRO. Tribunal de Justiça. Quinta Câmara Cível. Apelação Cível nº 2007.001.00013. Relatora: Des ${ }^{\text {a }}$. Cristina Tereza Gaulia. Rio de Janeiro, 06 de março de 2007. Disponível em: $<$ http://www.tjmg.gov.br> . Acesso em: 8 jun. 2008. EMENTA: Apelação Cível. Possessória. Reintegração. Função social da posse. Proteção à família e à criança. Utilização de áreas autônomas localizadas em mesmo imóvel. Composse. Caracterização. Reintegração de posse manejada por compossuidores residentes no andar térreo de casa de vila visando desalijar de acessão autônoma localizada no andar superior do mesmo imóvel a apelada e seu filho, este também co-proprietário. Direito de guarda que impõe o reconhecimento de unidade fática e jurídica entre o direito de posse da apelada e do menor Hugo Miguel, condômino do bem, o que determina que aquela não pode ser alijada do imóvel, pena de impossibilitar-se o direito ao exercício pleno da posse deste. Exercício da posse pela apelada e seu filho sobre área compartimentada do imóvel que, outrossim, não obstaculariza a posse parcial dos apelados, que podem livremente exercer seu direito de moradia sobre a parte térrea do imóvel. Dignidade da pessoa humana, proteção da família e da infância e a função social da propriedade que impõem seja privilegiado o direito de moradia do menor e de sua mãe. Inteligência dos art. 1, III c/c 226 e 227 da CF/88. Filtragem constitucional que exige releitura do art. 1199 do $\mathrm{CC} / 02$, para fins de se admitir a composse sobre áreas divisas de um mesmo imóvel, contanto que a utilização deste se dê de forma independente e sem prejuízo da composse alheia. Recurso conhecido e improvido.

63 Neste discutir, como já se teve oportunidade de criticar preteritamente, firmou posição o STF sobre a constitucionalidade ou não de dispositivo da Lei do Bem de Família que permite a penhora do único imóvel residencial de fiador de locação imobiliária, frente aos princípios da isonomia e da moradia como elemento indissociável da dignidade humana (Emenda $\mathrm{n}^{\mathrm{o}}$ 26, que alterou o artigo $6^{\mathrm{o}}$ da Constituição Federal). O voto do Ministro Cézar Peluso guiou os majoritários. Para o Ministro, a moradia está entre "direitos a prestações, 
dependentes da atividade mediadora dos poderes públicos", chegando a atentar, em seus argumentos, ao "equilíbrio do mercado". Durante os debates, chegou a ser invocado pelo Ministro Gilmar Mendes o princípio da autonomia da autodeterminação das pessoas: "um princípio que integra o próprio direito de personalidade". Para Mendes, trata-se de um princípio que, por tão elementar, sequer aparece no texto constitucional. O Ministro Celso de Mello tocou na discussão sobre a submissão das relações de caráter privado aos comandos constitucionais. No entanto, apesar de ter votado com a divergência, foi voto vencido, ao lado de Carlos Britto e Eros Grau, sendo vencedora a posição do relator por sete votos a três. ADOLFO, 2008, p. 93.

64 RIO DE JANEIRO. Tribunal de Justiça. Sexta Câmara Cível. Apelação Cível no 2007.001.03337. Relator: Des. Benedicto Abicair. Rio de Janeiro, 12 de setembro de 2007. Revista Magister de Direito Ambiental, Porto Alegre, v. III, n. 15, p. 143-149, dez 2007/jan. 2008. (Caderno imobiliário-jurisprudência)

RIO DE JANEIRO. Tribunal..., p. 148.

Idem, p. 148-149.

HABERMAS, Jürgen. A inclusão do outro: estudos de teoria política. São Paulo: Loyola, 2002, p. 129.

$\mathrm{Na}$ interessante figura de linguagem utilizada por Castanheira Neves, "do ius a distinguir e para além da lex". CASTANHEIRA NEVES, A. A crise actual da Filosofia do Direito no contexto da crise global da Filosofia: tópicos para a possibilidade de uma reflexiva reabilitação. Coimbra: Coimbra, 2003, p. 109.

\section{REFERÊNCIAS}

ADOLFO, Luiz Gonzaga Silva. Obras privadas, benefícios coletivos. a dimensão pública do Direito Autoral na sociedade da informação. Porto Alegre: Sergio Antonio Fabris, 2008.

; SANTOS, Liziane da Silva. Por quem os sinos dobram: os 20 anos da Constituição Federal de 1988 e a centralidade da dignidade da pessoa humana. Destaque Jurídico: revista de estudos jurídicos, Gravataí, ULBRA, v. 7, n. 7, p. 1733, 2008.

ALLENDE, Isabel. Zorro. começa a lenda. Rio de Janeiro: Bertrand Brasil, 2006.

ALEXY, Robert. Colisão de Direitos Fundamentais e realização de Direitos Fundamentais no Estado de Direito Democrático. Revista de Direito Administrativo, Rio de Janeiro, Renovar, n. 217, p. 74-5, jul./set. 1999.

2008.

. Constitucionalismo Discursivo. 2. ed. Porto Alegre: Livraria do Advogado,

. Direitos fundamentais, balanceamento e racionalidade. Ratio Juris, Belo Horizonte, v. 16, n. 2, p. 131-140, jun. 2003.

. Teoria da Argumentação Jurídica: A Teoria do Discurso Racional como Teoria da Justificação Jurídica. São Paulo: Landy, 2001.

. Teoría de los Derechos Fundamentales. Madrid: Centro de Estudios Constitucionales, 1997.

ALFONSIN, Jacques Távora. $O$ acesso à terra como conteúdo de direitos humanos fundamentais à alimentação e à moradia. Porto Alegre: Fabris, 2003. 
ALVES, Leonardo Barreto Moreira. A teoria do umbral do acesso ao Direito Civil como complemento à teoria do estatuto jurídico do patrimônio mínimo. Jus Navigandi, Teresina, v. 11, n. 1.535, 14 set. 2007. Disponível em: <http://jus2.uol.com. br/doutrina/texto.asp?id =10406>. Acesso em: 12 nov. 2007.

ARONNE, Ricardo. Por uma nova hermenêutica dos direitos reais limitados: das raízes aos fundamentos contemporâneos. Rio de Janeiro: Renovar, 2001.

. Propriedade e Domínio: reexame sistemático das noções nucleares de Direitos Reais. Rio de Janeiro: Renovar, 1999.

BARROSO, Luís Roberto. Neoconstitucionalismo e constitucionalização do Direito. Revista do Tribunal de Contas do Estado de Minas Gerais. Belo Horizonte, v. 65, n. 4, p. 20-50, out./dez. 2007.

BRASIL. Superior Tribunal de Justiça. Agravo de Instrumento no 749.108-RS (2006/0037616-5). Relator: Min. Carlos Alberto Menezes Direito. Agravante: Lojas Volpato Ltda. Advogado: Athos Gusmão Carneiro e outro(s). Agravado: Celular CRT S/A. Advogados: Oscar Luís de Morais. Rafael de Souza Santos e outro(s). Decisão. . Súmulas. Disponível em:

<http://www.stj.gov.br/portal_stj/publicacao /engine.wsp?

tmp.area=398\&tmp.texto=89622>. Acesso em: 30 out. 2008.

BRASIL. Supremo Tribunal Federal. Ação Direta de Inconstitucionalidade nㅜ 2.213. Relator: Min. Celso de Mello. Brasília, 4 de abril de 2004. Disponível em: <http://www.stf.gov.br/portal/constituicao/artigoBd.asp?item=31>. Acesso em: 30 ago. 2008.

. Tribunal Pleno. Recurso Extraordinário nº 387047/SC. Relator: Min. Eros Grau. Brasília, 6 de março de 2008. Disponível em: <http://www.stf.gov.br>. Acesso em: 8 ago. 2008.

<http://www.stf.jus.br/arquivo Súmula Vinculante no 11. Disponível em: /cms/jurisprudenciaSumulaVinculante/anexo/DJE_11.11.2008.pdf>. Acesso em: 22 jan. 2009.

CAGLIARI, Cláudia Taís; REIS, Jorge Renato dos. A função social dos contratos como instrumento de efetivação dos direitos fundamentais nas relações interprivadas. In. GORCZEVISKI, Clóvis; REIS, Jorge Renato dos. Direitos fundamentais sociais como paradigmas de uma sociedade fraterna: Constitucionalismo contemporâneo. Santa Cruz do Sul: IPR, 2008. p. 13-39.

CAMARGO, Ricardo Antônio Lucas. Os sem-teto, a especulação imobiliária e os direitos humanos. Revista da Faculdade de Direito da Universidade Federal de Minas Gerais, Belo Horizonte, n. 45, p. 373-399, jul./dez. 2004.

CASTANHEIRA NEVES, A. A crise actual da Filosofia do Direito no contexto da crise global da Filosofia: tópicos para a possibilidade de uma reflexiva reabilitação. Coimbra: Coimbra, 2003. 
CINTRA, Carlos de Araújo; GRINOVER, Ada Pellegrini; DINAMARCO, Cândido Rangel. Teoria Geral do Processo. São Paulo: Malheiros, 2007.

COMPORTI, Marco. La proprietà europea e la proprietà italiana. Rivista di Diritto Civile, Milão, Casa Editrice Dott. Antonio Milani, v. LIV, n. 2, p. 189-206, mar./abr. 2008.

COSTA MEIRELES, Ana Cristina. A eficácia dos direitos sociais. Salvador: Jus Podvim, 2008.

CUNHA, Alexandre dos Santos. Ensino jurídico e codificação civil no Brasil (18221916). In. TUTIKIAN, Cristiano (Org.). Olhares sobre o público e o privado. Porto Alegre: EDIPUCRS, 2008. p. 65-84.

DÍEZ-PICAZO, Luis María. Sistema de Derechos Fundamentales. 3. ed. Madrid: Thomson/Civitas, 2008.

DUGUIT, León. Las transformaciones generales del Derecho Privado desde el Código de Napoleón. 2. ed. espanhola. Tradução de Carlos G. Pousada. Madrid: Francisco Beltran Libreria, 1912.

DWORKIN, Ronald. Levando os direitos a sério. São Paulo: Martins Fontes, 2002.

FACHIN, Luiz Edson. A função da posse e da propriedade contemporânea (uma perspectiva da usucapião imobiliária rural). Porto Alegre: Fabris, 1998.

Renovar, 2008.

Questões do Direito Civil brasileiro contemporâneo. Rio de Janeiro:

. Teoria Crítica do Direito Civil. 2. ed. Rio de Janeiro: Renovar, 2003.

FERRAJOLI, Luigi. Democracia y garantismo. Madrid: Trotta, 2008.

FERREIRA FILHO, Roberval Rocha. Principais julgamentos do Superior Tribunal de Justiça. Salvador: Jus Podivm, 2008.

2008.

. Principais julgamentos do Supremo Tribunal Federal. Salvador: Jus Podium,

GANDOLFI, Giuseppe. Rivista di Diritto Civile. Milano, Anno LV, n. 2, p. 221-235, marzo/aprile 2008.

GUASTINI, Riccardo. Teoría e ideología de la interpretación constitucional. Madrid: Trotta, 2008.

HÄBERLE, Peter. La dignidad del hombre como fundamento de la comunidad estatal. Im. SEGADO, Francisco Fernández. Dignidad de la persona, derechos fundamentales, justicia constitucional. Madrid: Dykinson, 2008. p. 175-237. 
HABERMAS, Jürgen. $A$ inclusão do outro: estudos de teoria política. São Paulo: Loyola, 2002.

HANNA, Munira. Repersonalização e constitucionalização: superação do paradigma patrimonialista. Revista da Ajuris, Porto Alegre, v. 32, n. 98, p. 221-235, 2005.

LÔBO, Paulo Luiz Netto. Constitucionalização do Direito Civil. Revista de Informação Legislativa, Brasília: Senado Federal, n. 141, p. 99-109, 1999.

MARTINS-COSTA, Judith Hofmeister. O Direito Privado como um "Sistema em Construção". Revista da Faculdade de Direito da UFRGS, Porto Alegre, v. 15, p. 129-154, 1998.

2002.

. Diretrizes teóricas do Novo Código Civil brasileiro. São Paulo: Saraiva,

(Org.). A reconstrução do Direito Privado. reflexos dos princípios, diretrizes e direitos fundamentais constitucionais no Direito Privado. São Paulo: Revista dos Tribunais, 2002.

MELO, Marco Aurélio Bezerra de. Novo Código Civil anotado: v. V: Direito das Coisas. Rio de Janeiro: Lumen Juris, 2003.

MINAS GERAIS. Tribunal de Justiça. Décima Quarta Câmara Cível. Apelação Cível n 1.0095.07.001439-4/001. Relator: Des. Antônio de Pádua. Belo Horizonte, 14 de fevereiro de 2008. Disponível em: <http://www.tjmg.gov.br>. Acesso em: 7 jun. 2008.

MORSELLO, Marco Fábio. Direito Civil Constitucional e o Direito de Propriedade no Brasil e no Direito Comparado. Revista da Pós-Graduação da Faculdade de Direito da Universidade de São Paulo, São Paulo, Síntese, v. 2, p. 93-125, 2000.

OLIVEIRA NETO, Francisco José Rodrigues de. O Poder Judiciário na concretização do Estado Democrático de Direito após 1988. Im. SCAFF, Fernando Facury (Org.). Constitucionalizando direitos: 15 anos da Constituição brasileira de 1988. Rio de Janeiro: Renovar, 2003. p. 55-74.

PACHECO, Celso A. Fiorillo. Fundamentos Constitucionais do Direito Ambiental brasileiro, 2007. Palestra proferida em 26 de outubro de 2007, no VI Congresso de Direito da ULBRA Gravataí: O Século XXI e os Novos Direitos. Porto Alegre, 2007.

PERLINGIERI, Pietro. Perfis do Direito Civil. 2. ed. Rio de Janeiro: Renovar, 2002.

PILATI, José Isaac. A função social da propriedade a partir da Constituição de 1988: o resgate da dimensão coletiva. Destaque Jurídico: revista de estudos jurídicos, Gravataí, Ulbra, v. 7, n. 7. p. 201-210, 2008.

PULIDO, Carlos Bernal. El principio de proporcionalidad y los derechos fundamentales. 3. ed. Madrid: Centro de Estudios Políticos y Constitucionales, 2007.

RICOEUR, Paul. Hermenêutica e Ideologias. Petrópolis: Vozes, 2008. 
RIO GRANDE DO SUL. Tribunal de Justiça. Vigésima Câmara Cível. Apelação Cível no 70015377393. Relator: Des. Glênio José Wasserstein Hekman. Porto Alegre, 14 de junho de 2006. Disponível em: <http://www.tj.rs.gov.br>. Acesso em: 29 nov. 2007. - Vigésima Segunda Câmara Cível. Agravo de Instrumento $\mathrm{n}^{\circ}$ 70016021024. Relatora: Desembargadora Mara Larsen Chechi. Porto Alegre, 26 de outubro de 2007. Disponível em: <http://www.tj.rs.gov.br>. Acesso em: 29 nov. 2007.

RIO DE JANEIRO. Tribunal de Justiça. Quinta Câmara Cível. Apelação Cível no 2007.001.00013. Relatora: Des ${ }^{a}$. Cristina Tereza Gaulia. Rio de Janeiro, 06 de março de 2007. Disponível em: <http://www.tjmg.gov.br>. Acesso em: 8 jun. 2008.

. Sexta Câmara Cível. Apelação Cível no 2007.001.03337. Relator: Des. Benedicto Abicair. Rio de Janeiro, 12 de setembro de 2007. Revista Magister de Direito Ambiental, Porto Alegre, v. III, n. 15, p. 143-149, dez 2007/jan. 2008. (Cademo imobiliário-jurisprudência)

SILVA FILHO, José Moreira da. Transformações jurídicas nas relações privadas. Inr. ROCHA, Leonel Severo; STRECK, Lenio Luiz (Org.). Anuário do Programa de PósGraduação em Direito. São Leopoldo: Unisinos, 2003. p. 143-95.

TEPEDINO, Gustavo. Problemas de Direito Civil-Constitucional. Rio de Janeiro: Renovar, 2000.

. Temas de Direito Civil. 2. ed. Rio de Janeiro: Renovar, 2001.

TUTIKIAN, Cristiano. Sistema e Codificação: o Código Civil e as cláusulas gerais. In ARONNE, Ricardo (Org.). Estudos de Direito Civil-Constitucional. Porto Alegre: Livraria do Advogado, 2004. V. 1, p. 17-84.

Recebido para publicação 15/07/2009

Aceito para publicação 28/12/2009 